\title{
KMT5A Gene
}

National Cancer Institute

\section{Source}

National Cancer Institute. KMT5A Gene. NCI Thesaurus. Code C73664.

This gene plays a role in protein methylation and epigenetic control of gene expression. 